\title{
FROM DOSSIER ON SPECIFIC FABRICATIONS
}

\author{
Carlos Quijon, Jr. \\ University of the Philippines-Diliman \\ carlosquijonjr@gmail.com
}

\begin{abstract}
About the Author
Carlos Quijon, Jr. writes essays and poetry. His works have been published in High Chair, DiscLab, Cabinet, The Literary Apprentice, and The Kritika Kultura Anthology of New Writing in English. He was a fellow in Para Site's Workshops for Emerging Art Professionals and was also a fellow for Hybrid Text in the 13th Ateneo National Writers Workshop in 2015. He is the founding editor of transit, an online intermedia journal, and the co-founder of modo, a design initiative for arts-related projects. His chapbook DECOMPOSITION was published in 2012.
\end{abstract}




\section{FIXATIONS}

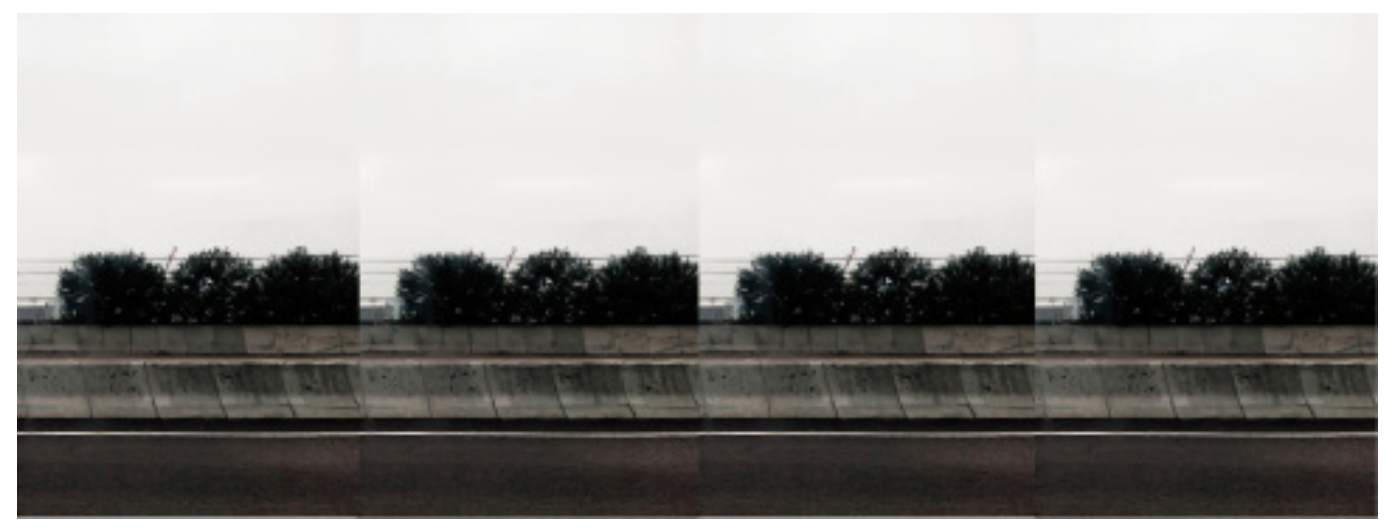

The shadow is a mark of longing. In Natural History, Pliny the Elder traces the history of painting to a shadow. Faced with her lover's nearing departure, a maiden traced his shadow onto a rock with the help of just the dimmest of lamps. The origin of photography, too, is a story of shadows, and longing, and death. As Henry Fox Talbot baptized it, photography is the art of fixing a shadow. One of its earlier versions, the photogram, involve nothing but an object's shadow lingering on lightsensitive material. Nothing more than a trace of something that has been there and now is not. "The photograph is in no way a presence," says Barthes, "its reality is of the having-been-there." 


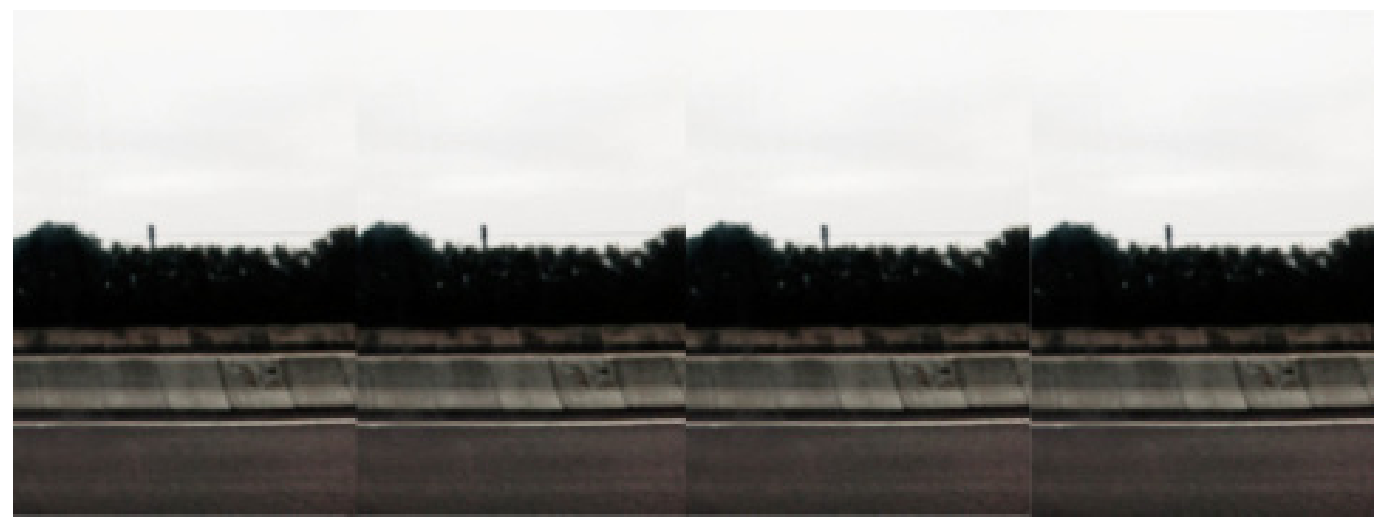

According to the Allegory of the Cave, what we see as our reality is a mere shadow of what is out there. In Plato's idealism, our reality is just a copy of ideal forms, an imperfect shadow of truth. We conceive of photography as record: factual, faultless. But let's say a photograph is, like images for Plato, a shadow, a lie? Let's say photographs are supposed to be shadows of our reality. In the poem about a photograph, we are talking about fulgurations, a rumor, soft porn. Let's say, like in the poem: photography is mere rumor. Shadows flicker and, like rumors, err. In the same time that it takes for me to describe what the shadow I see looks like, it has already morphed into something else. My last request is for you to stay still, says the beloved to the lover. 


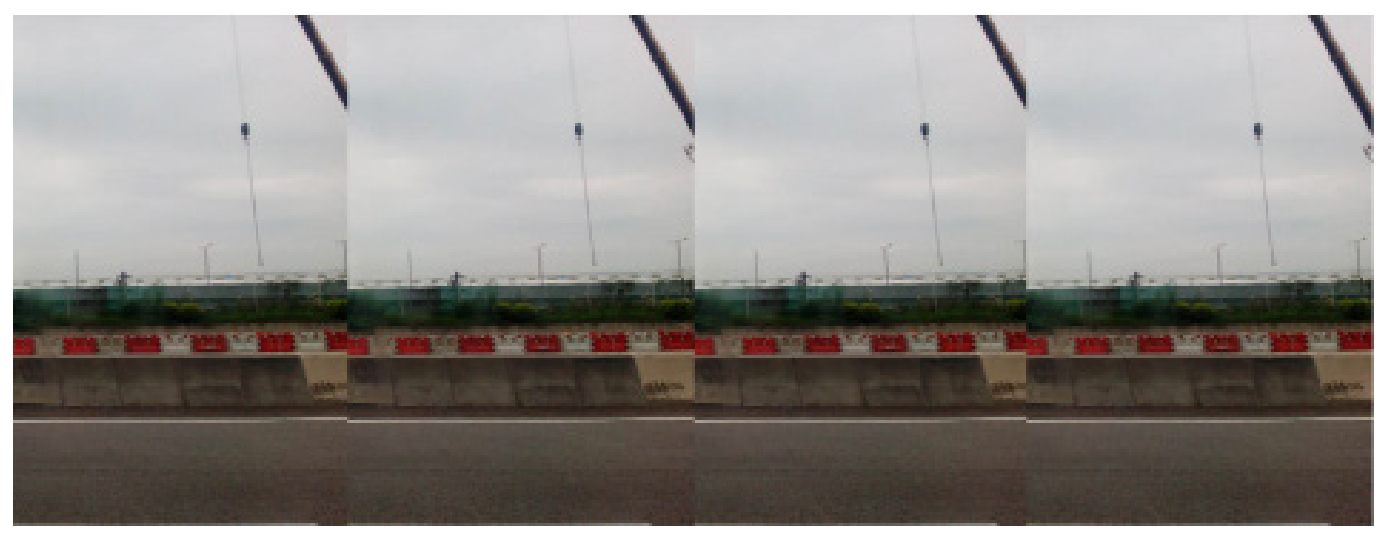

I am unsure of what to make of photographs that express their utmost fidelity to the clarity of reality - with their hate against being against-the-light, or being out-of-focus. Isn't that what we should be wanting? To become mere mark, trace, specter. "I want to be a shadow in your life." I cannot think of anything as unsure, as unspecific as a shadow. What more do we want of reality? We are already here. 


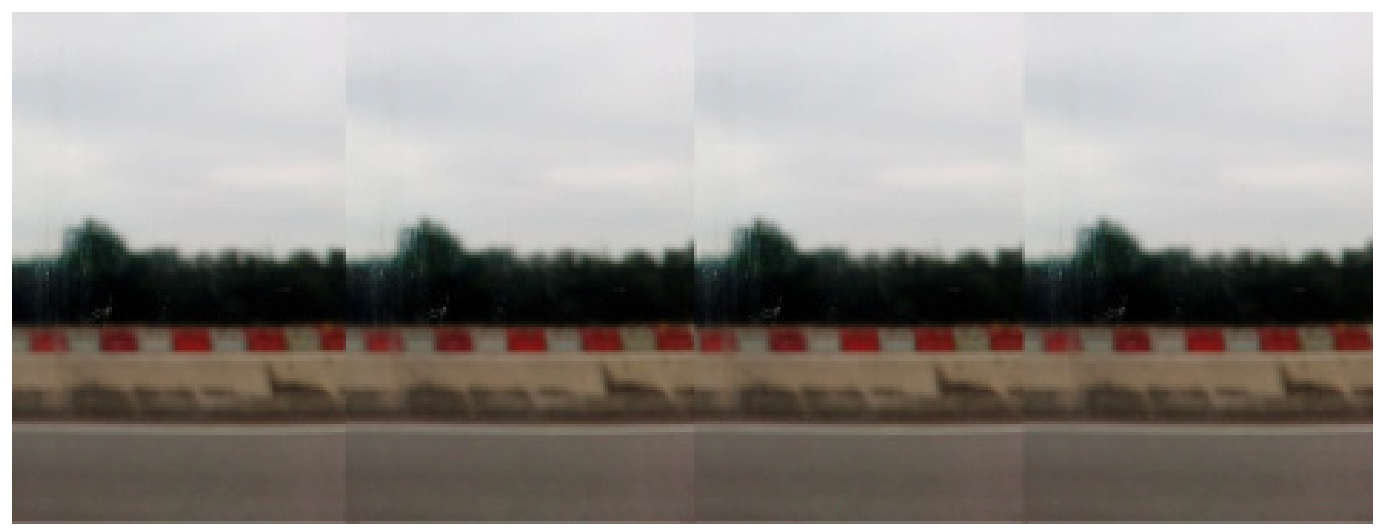

Being against-the-light is being against arresting certainty, being out-of-focus is siding with the drawn-out and the indeterminate. Isn't that what we want? To be progressively enchanted? To forever be laboring toward an understanding? To never run out of things to be mystified about, mysteries to figure out? When I took the photograph, the face became a shadow. The sea reflected too much light. The face became a mark of longing. Looking at the distance. Outside the frame could have been the lover coming back. Outside the frame could have been a form of finality-like death or afterlife, or truth. I am fascinated with these fabrications. 


\section{SCENES OF A POSSIBLE ENCOUNTER (I)}

[Waves unerring. Birds. Opaque sound heard by water-clogged ear. In the distance, by the shore, children chasing water as it retracts back to sea. Sand gently eroding. Feet dipping into cold water.] 


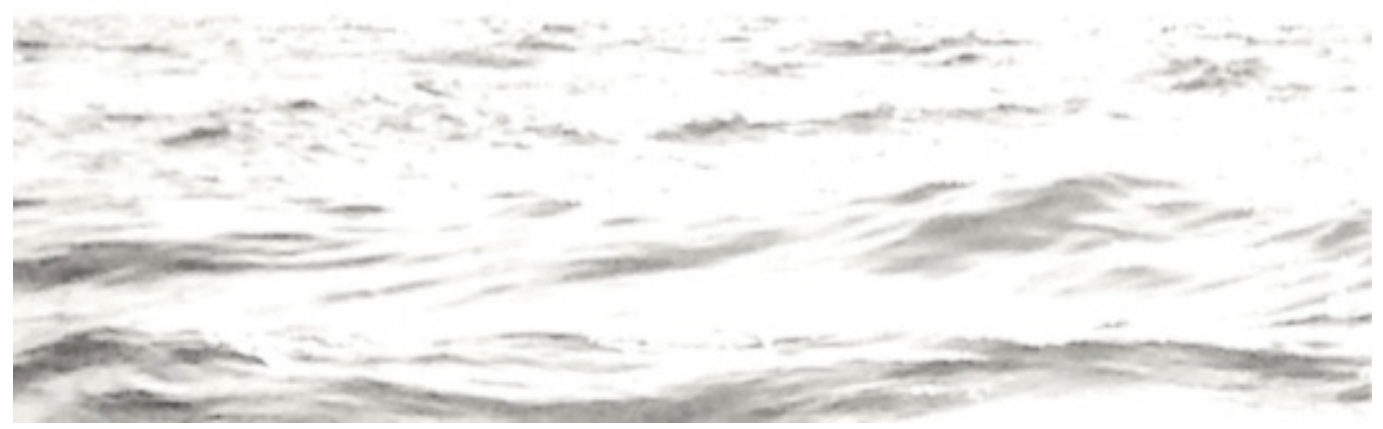

Kritika Kultura 26 (2016): -671

(ㄷ) Ateneo de Manila University <http://kritikakultura.ateneo.net> 


\section{[SCENE: CONFRONTATION]}

[Man-at-sea (1) - age unknown, taller than (2). Man-at-sea (2) - age unknown, shorter than (1). In the middle of the sea. Both men walking on their toes, bobbing their bodies with the waves that approach and every so often submerge them.]

Man-at-sea (1): $\quad$ In the middle of it all, she shouted she wanted to pee. We were in the pool. She was drunk. As soon as she said that, I felt the water warm. She put her hand over my mouth when she saw I was about to laugh.

Man-at-sea (2): $\quad$ Do you know that beyond the horizon is a waterfall? We are always tricked-the sea becoming wider, water becoming deeper-that we back away and turn around before the edge; that's why we never notice.

Man-at-sea (1): $\quad$ In the middle of it all, she whispered she wanted to bury me in sand. We were by the beach, broad daylight. People stared. She kissed me.

Man-at-sea (2): Do you know that beyond the horizon is an infinity of horizons? We are always tricked-the promise of land, the possibility of touch-that we swim forward, against our body's telling us no please stop, against its telling us we are tired, that we soldier on, we hope for some form of finality.

Man-at-sea (1): $\quad$ Forgive me, the woman I love left me. 


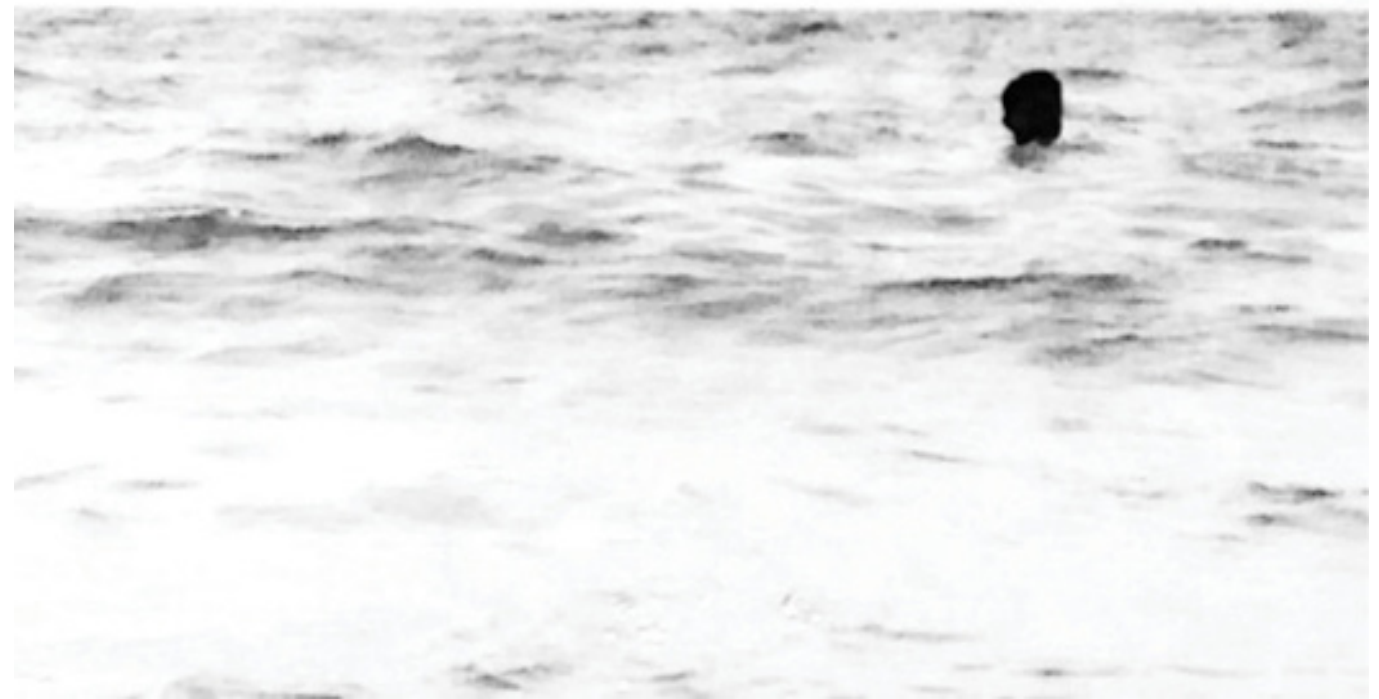

Kritika Kultura 26 (2016): -671

(C) Ateneo de Manila University <http://kritikakultura.ateneo.net> 


\section{[SCENE: CONFLICT]}

[Man-at-sea (1) and (2) again. Same incomprehensible sea.]

[Every so often Man-at-sea (2) bends his knees to have his eyes on the same level as the water's surface. He is watching the waves flatten. Every so often he straightens up and spits saltwater. Every so often he hits his head with his palm to take out water from his ears. Every so often he dives deep, curls into a ball, and waits for his body to float.]

[Man-at-sea (2) is jolted by something, some creature that brushed against his ankle. The water is dark, he can't see anything from the water's surface. He stops and jumps to disturb the creature, to scare it away from him. After a second, Manat-sea (1) surfaces-his eyes closed, his hair matted onto his head, his mouth open.]

Man-at-sea (1): Look at what I found!

[The sea closes itself after his surfacing.]

[END] 


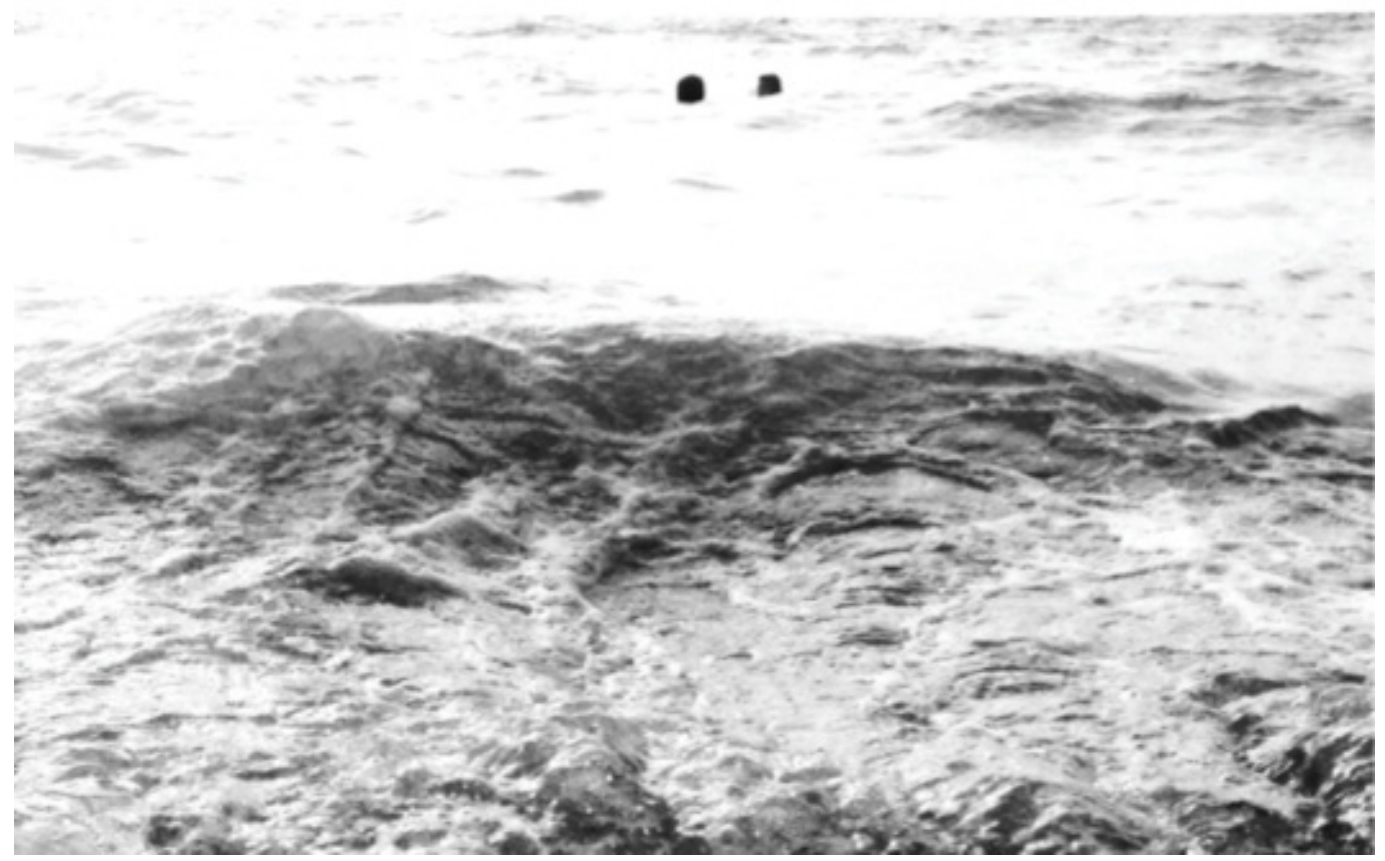

Kritika Kultura 26 (2016): -671

(ㄷ) Ateneo de Manila University

<http://kritikakultura.ateneo.net> 


\section{[SCENE: RESOLUTION]}

[Same men. Continuous revision of waves. Surface glinting, catching light. Bodies bobbing with the waves. Feet treading water.]

Man-at-sea (1): $\quad$ [Not looking directly at his face. Some waves swallow him. Some waves do not.] She left when I told her I wanted to leave.

Man-at-sea (2): $\quad$ As a conclusion, I would like to assert that the sea never flattens. The sea shimmers. The sea is everything of the same. The sea continues. The sea revises. The sea directs.

[Man-at-sea (3) watches from afar. What he hears is the sound of water. What he hears is the opacity of sound when water gets trapped in the ears. What he sees is the sea perpetually giving off glare.]

[END] 


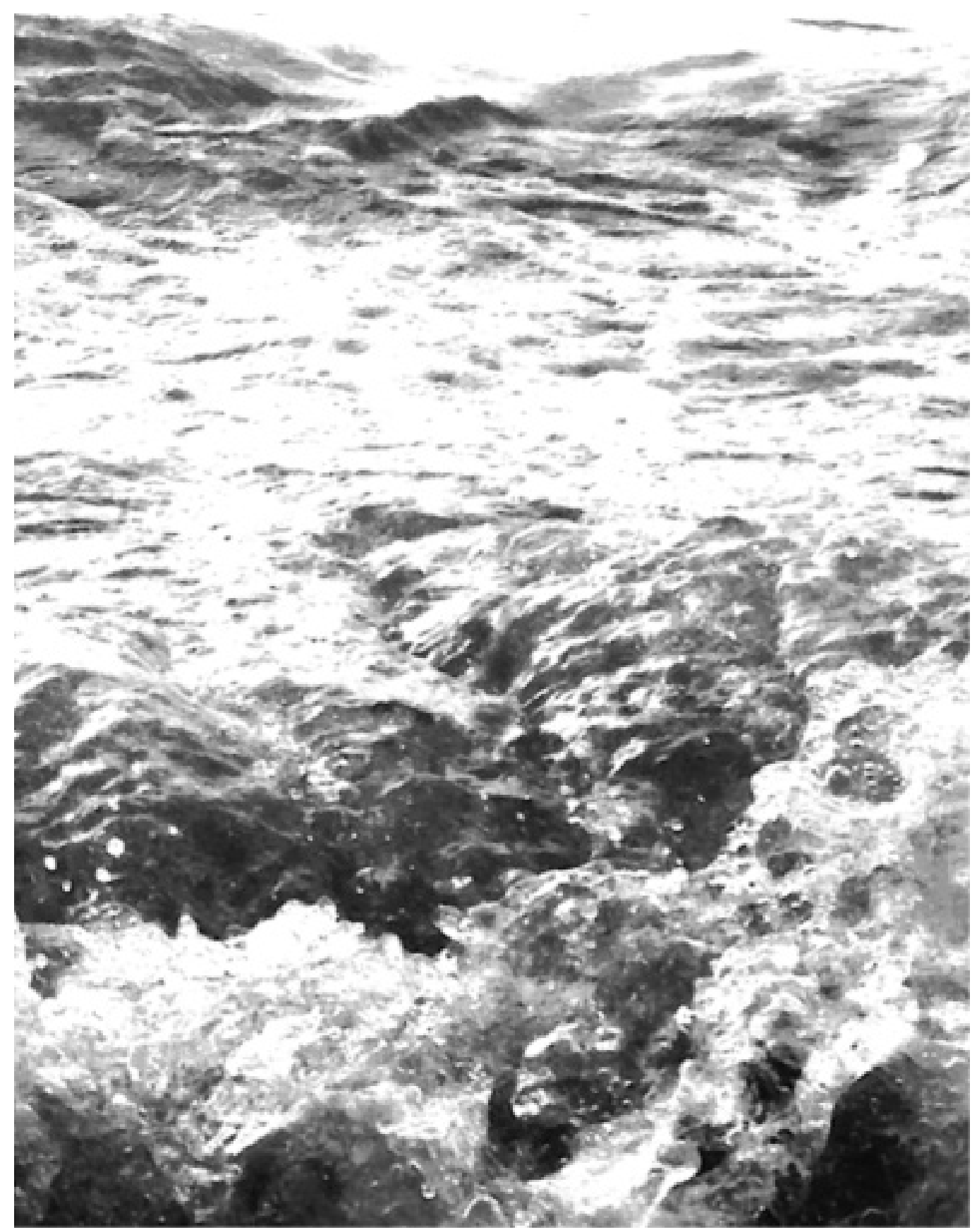

Kritika Kultura 26 (2016): -671

(ㄷ) Ateneo de Manila University

<http://kritikakultura.ateneo.net> 
SCENES OF A POSSIBLE ENCOUNTER (II)

I took the photo before a dead body was found by the shore. The body had a face. I think this is his face. I think he was one of the shadow-faced men I had caught in this photo [his companion not in the photo]. Although, even I don't know who the specific man in this photo is. I was too far from him. The man and his companion [not in the photo] looked serious, were talking about something serious. They went from hushed to aggravated and then hushed again. When I conceded to the desire to know who the man was, who this shadow-faced man was, I tinkered with the photo. The result of my editing is a furrowed brow and a mouth open as if he were in the middle of saying something in anger or disappointment-Why don't you just kill me now? or Wasn't it you who said we will always be true? 


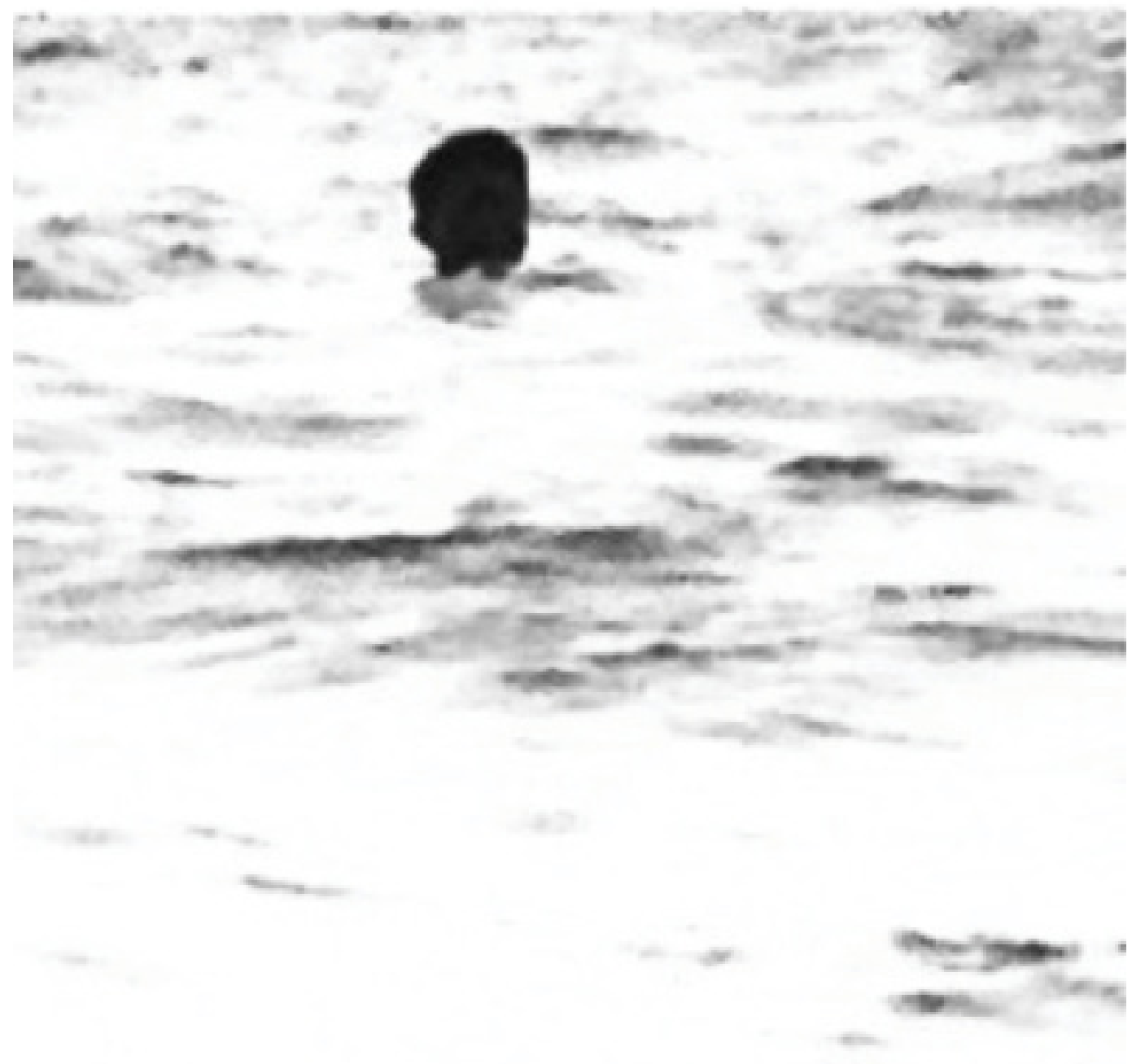

Kritika Kultura 26 (2016): -671

(ㄷ) Ateneo de Manila University 
When do we know if the photograph is tricking us? The men and women at the beach gathered in front of the man who drowned. They fished out their camera phones from their pockets and started, sincerely, to document what was happening - the drowned man isn't moving. [Crowd murmuring] The man who dragged the body to the shore is a good man. [Crowd murmuring. People breaking away from the crowd to bring in more people into the crowd.] The man who dragged the body breathes heavily, his skin burnt, his voice breaking. [Man sits down beside the body. He looks up to the crowd.]

Man 1: $\quad$ Can someone call someone who knows what to do?

[Continued murmuring. Someone from the crowd starts to pray. Someone from the crowd documents this holy moment.] 

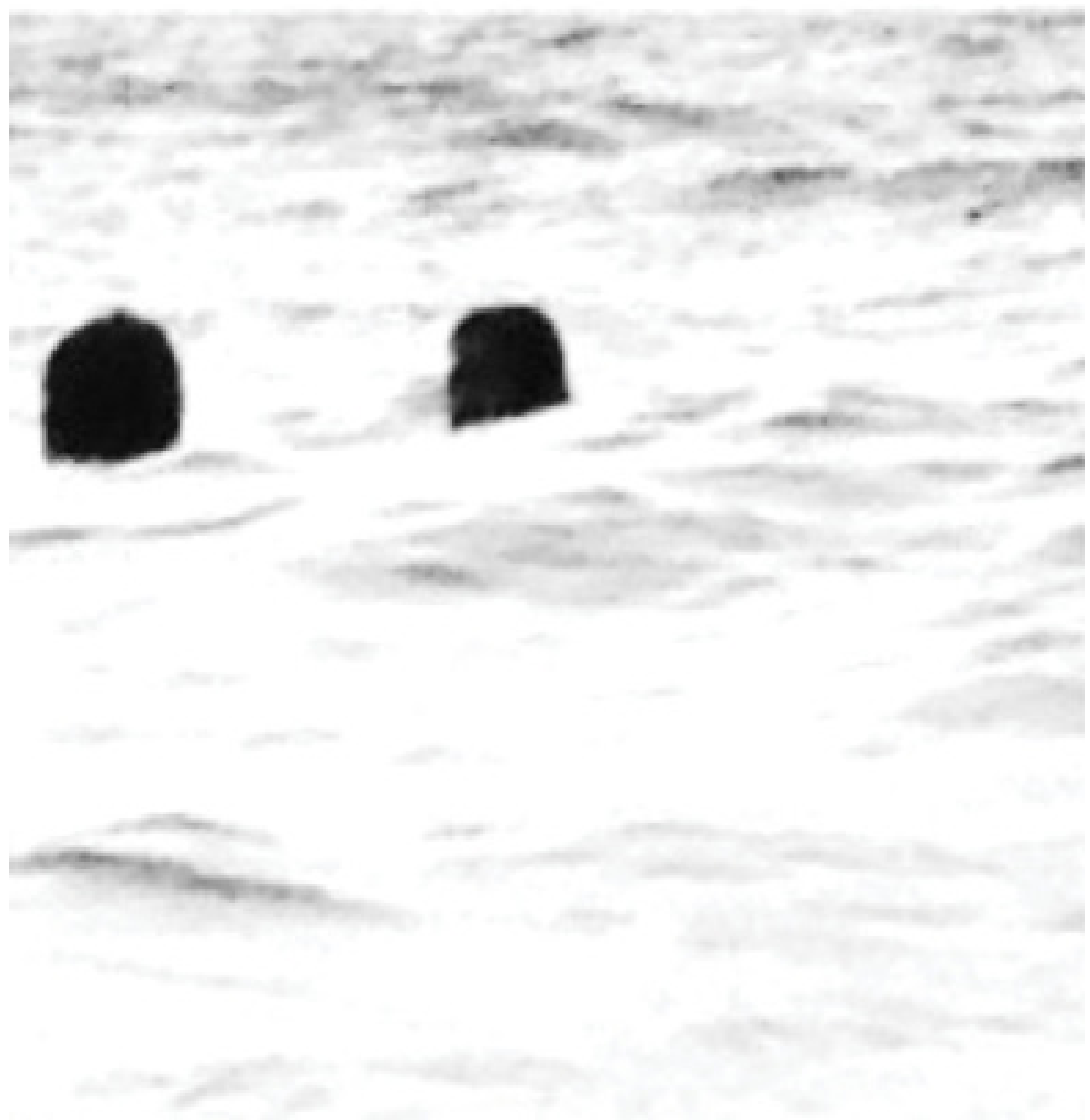

Kritika Kultura 26 (2016): -671

(ㄷ) Ateneo de Manila University <http://kritikakultura.ateneo.net> 
In Antonioni's Blow-up, a photographer thinks he has witnessed a murder. He believes that there is a murder, believes there is a body, only that the limits of human vision obscure it. The photographer prints his photograph, zooms in (he finds a hand with a gun, a gun pointed at someone, a body left dying), and prints it again, until he has zoomed in into an abstraction that he believes is a human body. By the end of the movie he goes to his studio and finds it trashed, his blow-ups gone missing. In his final blow-up, a black and white photo, what we see are patches of black and white pixels, and near the center, a grainy wisp of smoke rising. 


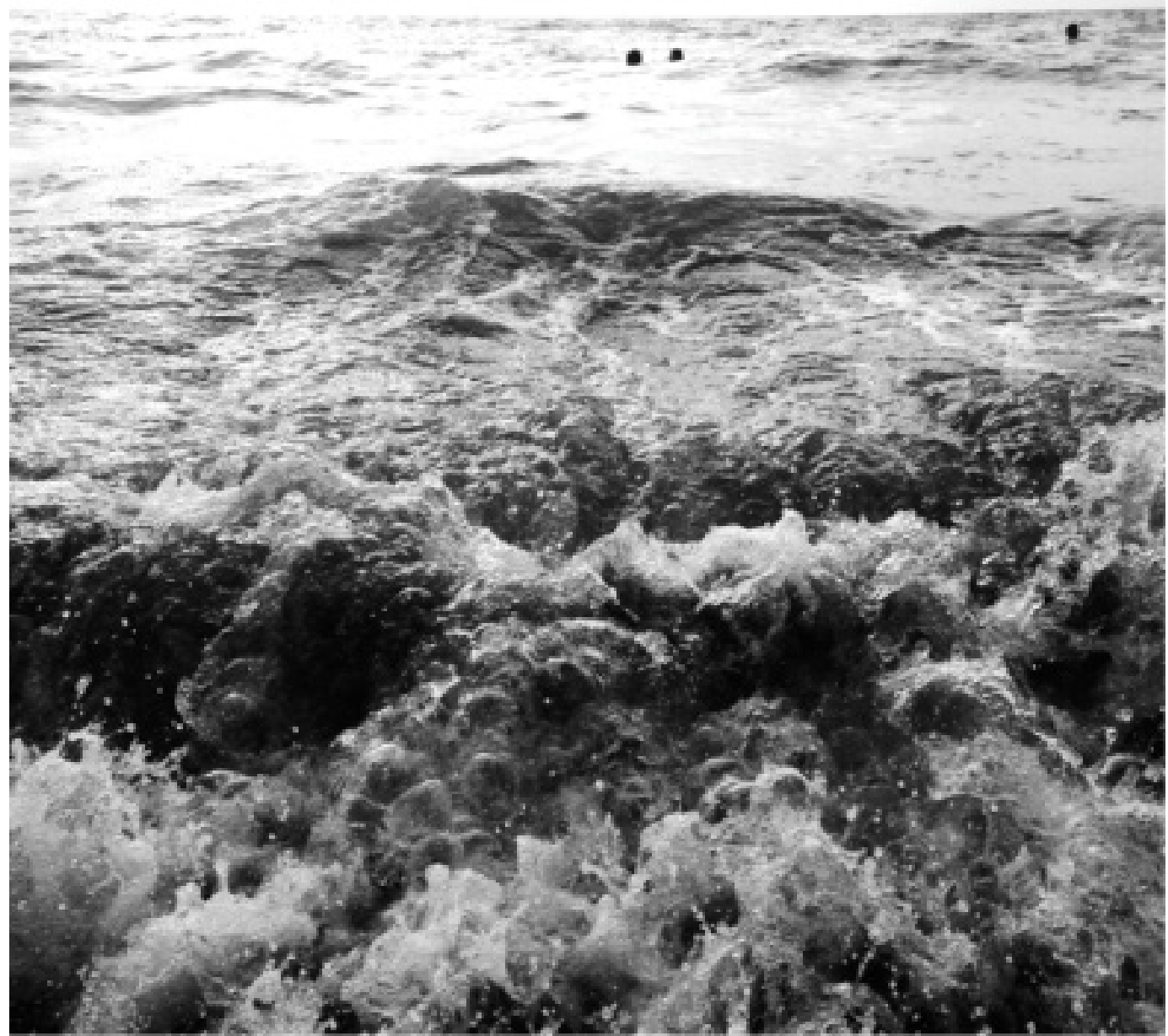

Kritika Kultura 26 (2016): -671

(c) Ateneo de Manila University

<http://kritikakultura.ateneo.net> 
The frame constitutes what I know. The rest I fabricate. In this, the optical zoom is important. The digital zoom is important. The brightness and contrast are important. The crop, if used carelessly, is primary. I do not see anything productive repeating the symmetry of what we see. Within the frame, any similarity with reality, the referent, is obtuse. "Give us a few negatives of a thing worth seeing, taken from different points of view, and that is all we want of it... [p]ull it down or burn it up if you please." I am showing you the events that lead to a possible drowning. There is a swelling in the belly and a tenderness in his body. What is difficult to understand about love? 


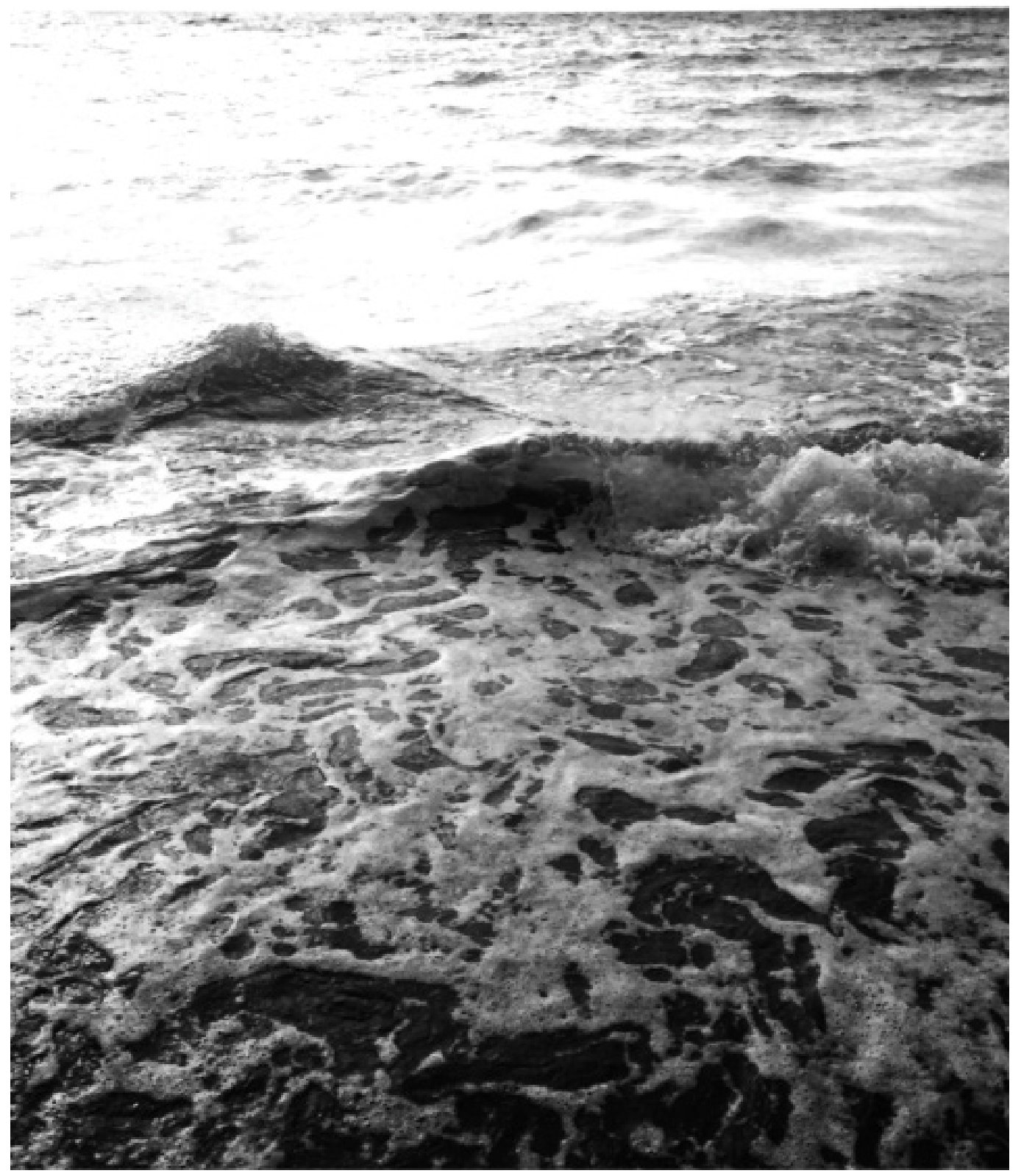

Kritika Kultura 26 (2016): -671

(ㄷ) Ateneo de Manila University

<http://kritikakultura.ateneo.net> 